\title{
Problems Faced By Physical Handicapped Students In Educational Institutions In District Kohat
}

\author{
Ishtiaq Hussain, IER, Kohat University, Pakistan \\ Muhammad.Bashir, KIMS, Kohat University, Pakistan \\ Muhammad Naseer ud Din, IER, Kohat University, Pakistan \\ Muhammad Naeem Butt, IER, Kohat University, Pakistan \\ Shagufa Akhter, Foundation University, Rawalpindi, Pakistan \\ Hafiz Inamullah University of Peshawar, Pakistan
}

\begin{abstract}
The purpose of the study was to explore the problems faced by physical handicapped students in normal educational institutions and to find solutions to the problems faced by physical handicapped students. All the physical handicapped students studying in educational institutions in District Kohat constituted the population of the study. The study was delimited to the physical handicapped students studying in 20 general educational institutions at four levels; i.e., Elementary, Secondary, Higher Secondary and Higher Education. Forty students, both male and female, were selected from 20 educational institutions using a random sampling technique. A questionnaire was constructed using the problems faced by physically handicapped students. The results of the investigation revealed that the physically handicapped children constitute 2-3\% of the population and the majority of them are lame. They face a lot of problems while studying in normal educational institutions.
\end{abstract}

Keywords: Physically Handicapped; attitudes; disability; adjustment; classification

\section{INTRODUCTION}

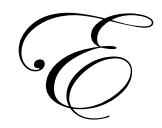

ducation is a powerful catalyzing agent which provides mental, physical, ideological and moral training to individuals so as to enable them to have full consciousness of their mission, of their purpose in life, and to equip them to achieve that purpose. It is an instrument for the spiritual development, as well as the material fulfillment, of human beings. Within the context of Islamic perception, education is an instrument for developing the attitudes of individuals in accordance with the value of righteousness to help build a sound Islamic society (Govt. of Pakistan, 1998).

The need to educate its disabled population has gained increasing recognition in Pakistan in the last two decades (Miles, 1991).The International Year for Disabled Persons (1981) and the UN Declaration of 1983-92 as the decade of the disabled has aroused interest in the field of education for SWPD. In 1980's, the Government of Pakistan undertook a crash program of expansion on special education provisions, improving both quantity and quality of existing facilities.

Since physically handicapped students constitute $10 \%$ of our total population, the research study in this connection will be helpful to solve their problems a better way.

In Pakistan, research on education of the orthopedically handicapped has not received the attention it deserves. It is only recently that some attention is being paid. Education of the handicapped has national significance also; hence, there is the need to provide education suited to them. It will help to prevent, reduce or eliminate the 
problems in the field of academics, communication, loco motors, and adjustment of orthopedically handicapped children.

The orthopedically handicapped pupils are just normal children, except for their physical deformity; therefore, it is necessary to provide special facilities in addition to the facilities provided to normal children (Zaib \& Alia, 2006).

The number of students with physical disabilities entering general education is increasing. It has therefore become essential to understand how they are adjusting to their school environments and interacting with their nondisabled peers.

Education further provides a setting for interaction and sound social experiences between the students who have physical disabilities and the students who do not have disabilities. In such a setting, students learn that they are more alike and less different (Nelsworth, 1982).

\section{REVIEW OF RELATED LITERATURE}

After reviewing the bulk of research work done in the field of disability, it can be easily concluded that a very little portion of this research work is focused on the educational aspect and life experiences of students with physical disabilities. However, a general agreement can be found that problems of people with physical disabilities are not physical, but rather social and psychological (Bank, 1994)

Literature reveals that people with disabilities have always been discriminated and stigmatized across cultures for thousands of years (Livneh, 1982).

Social scientists, child psychologists and educators agree that school can provide the opportunity and appropriate environment for personal, interpersonal, social growth, and development for all, including adolescents with disabilities, to the maximum extent possible. In general classroom, educational institutions can be instrumental in changing attitudes and enhancing the social adjustment of students with disabilities (Hallahan \& Kauffman, 1991).

\section{Classification of Special Children} children:

The disabled children can be classified in eight categories according to international classification of special

$\begin{array}{ll}\text { - } & \text { Hearing Impairment } \\ \text { - } & \text { Visual Impairment } \\ \text { - } & \text { Physical Retardation } \\ \text { - } & \text { Severe Handicaps } \\ \text { - } & \text { Learning Disability } \\ \text { - } & \text { Communication Disorder } \\ & \text { Gifted/talented children }\end{array}$

In most countries, this classification system is recognized.

As listed in the National Policy for the Education and Rehabilitation of the Disabled (1988 Review), the special children in Pakistan are categorized as follows (Aqila, 2003):

- $\quad$ Mental Disability

- $\quad$ Visual Impaired

- $\quad$ Hearing Impaired 
- $\quad$ Physical Disability

- $\quad$ Multiple/complex Disability

- $\quad$ Not Classied

\section{RESEARCH METHODOLOGY}

\section{Population}

All physically handicapped students studying in educational institutions in District Kohat constituted the population of the study.

\section{DELIMITATION OF THE STUDY}

The study was delimited to the physically handicapped students studying in 20 general educational institutions at four levels; i.e., Elementary, Secondary, Higher Secondary and Higher Education.

\section{SAMPLE}

Forty students, both male and female, were selected from 20 educational institutions using a random sampling technique.

\section{RESEARCH INSTRUMENT}

A questionnaire was constructed using the problems faced by physically handicapped students in general educational institutions for this study.

\section{CONCLUSIONS}

The following major findings of the research were concluded after the study:

- $\quad$ Physically handicapped children constitute $2-3 \%$ of the population and the majority of them are lame.

- There is no specific path for the handicapped students while coming to school and then to the class room.

- $\quad$ The schools are lacking wheel chairs and sign boards for the physically handicapped students.

- The majority of school buildings were not spacious enough to allow the principal in providing facilities to them.

- $\quad$ No school has a specific convenient toilet and wash room for them. For physical fitness, there were no play grounds for them.

- $\quad$ In most of the schools, teachers were not specially trained to teach physical handicapped students.

- The majority of the teachers gave special attention to them, but they do not have specific aids in the class room to teach them.

- $\quad$ Most of the teachers have kept the parents informed about their educational matters and progress.

- $\quad$ Students have good interaction with the physically handicapped students; however, the majority of them were called by specific nick names.

- $\quad$ Physically handicapped students face educational problems, but all the teachers help them in the solution of these problems.

- $\quad$ Most of the students were born handicapped.

\section{RECOMMENDATIONS}

- $\quad$ Physically handicapped children constitute 2-3\% of the population, so their problems should be explored in a better way. 
- $\quad$ Each school should have a specific path for the handicapped students while coming to school and then to the class room. The schools should be provided with wheel chairs and sign boards for the physical handicapped students to facilitate them.

- The schools should be provided with a specific convenient toilet, wash room, and play ground for the physically handicapped students to facilitate them.

- Due attention should be given to the physically handicapped students by the administration; higher authorities should arrange special training programs for the handicapped.

- $\quad$ Course contents regarding problems of the physically handicapped students should be included at all levels of teacher training programs.

- $\quad$ Special teaching aids should be provided in the class room to teach physically handicapped students.

- $\quad$ Parents should be informed about educational matters and progress of physical handicapped students.

- The teachers and other normal students' interaction should be very cooperative with the physically handicapped students regarding their problems.

\section{AUTHOR INFORMATION}

Dr Ishtiaq Hussain is working as Director at IER, Kohat University, Pakistan. He has 25 years teaching experience to his credit. He is teaching to Ph.D and M.Phil level scholars. He published a number of research papers in different journals and presented papers in national as well as international conferences.

Dr. Muhammad.Bashir did his FCPS in Medicine in 1977 at the age of 26. He has experience in teaching Physiology and as a consultant Physician in the Health Department.

Dr Muhammad. Naseer ud Din is working as Assistant Professor, IER, Kohat University. He did his Ph D at Arid Agriculture University, Rawalpindi, Pakistan. He published a number of research papers in different journals.

Muhammad Naeem Butt is working as a Lecturer in IER, Kohat University. He did his M Phil at Sarhad University, Peshawar Campus, Pakistan.

\section{REFERENCES}

1. Aqila, Khatoon. 2003. A Historical and Evaluative study of Special Education in Pakistan. PhD Thesis, Department of Education, Karachi University, Karachi, Pakistan.

2. Bank, J. A. 1994. An Introduction to Multicultural Education. Boston: Allyn and Bacon.

3. Govt. of Pakistan. 1998. National Education Policy (1998-2010): Ministry of Education, Islamabad. P. 5, 39-41, 108-110.

4. Hallahan, D. and Kauffman, J. 1999. Introduction to special Education, Englewood, Cliffs, NJ Prentice Hall

5. $\quad$ Livneh, H. 1982. Rehabilitation Literature (Attitudes) V 43 n11-12 . p-338-347. Eric.ed.gov.

6. Miles, M. 1991. Mental Handicapped Services: Development Trends in Pakistan. Mental Health Centre, Peshawar, Pakistan.

7. National Policy Draft for Education and Rehabilitation of the disabled (1988 Review). Islamabad. Govt. of Pakistan Ministry of Health, Special Education and Social Welfare.

8. Nelsworth, J.T. 1982. Assessment in Special Education. USA, An Espen Publication

9. Zaib-un-Nisa and Alia Shah. 2006. Problems Faced by Physically Handicapped Students at Secondary School Level in District Kohat, M Ed Thesis, Institute of Education \& Research, Kohat University of Science \& Technology, Kohat, Pakistan. 